GEOSPORT FOR SOCIETY
$\begin{gathered}\text { GEOSPORT } \\ \text { SOCIETY }\end{gathered}$
Scientific Journal founded in 2014 under aegis of University of Oradea (Romania),
University of Debrecen (Hungary), University of Gdánsk (Poland)
ISSN 2393-1353
Edited by Oradea University Press
1, University Street, 410087, Oradea, Romania
Journal homepage: http://geosport.uoradea.ro/geosport.html

\title{
Recreational Activities and Motivation Among Young People
}

\author{
Antonia KINCZEL ${ }^{1 *}$, Gergely MAKLÁRI ${ }^{2}$, Anetta MÜLLER ${ }^{3}$
}

\author{
1. University of Debrecen, 4032 Debrecen, Hungary, e-mail: antokincz@gmail.com \\ 2. University of Debrecen, 4600 Kisvárda, Hungary, e-mail: maklarigergo88@gmail.com \\ 3. University of Debrecen, 4032 Debrecen, Hungary, e-mail: muller.anetta@econ.unideb.hu, muller.anetta@gmail.com \\ * Corresponding author
}

Citation: Kinczel, A., Maklári, G., \& Müller, A. (2020). Recreational Activities and Motivation Among Young People. Geosport for Society, 12(1), 53-65. https://doi.org/10.30892/gss.1206-059

Article history: Received: 10.03.2020; Revised: 20.04.2020; Accepted: 18.05.2020, Available online: 20.05.2020

\begin{abstract}
These days, a sedentary lifestyle lacking in exercise has been dominating people's lives, and very few people are motivated to do sports. Motivation is a highly important factor, as it plays a role in people's daily lives, actions or even in sports. As for our free time, both passive and active recreational activities appear, corresponding to trends. In terms of an active lifestyle and prevention, the role of recreational sports is becoming increasingly appreciated among health-conscious consumers, who prefer to practice them. Several studies have shown that regular recreational sports represent prevention against several lifestyle-related diseases (such as diseases resulting from stress, obesity, cardiovascular diseases, type 2 diabetes, certain tumorous conditions, etc.). This is why recreational sports are a great means of prevention, being able to preserve individuals' health in a cost-efficient manner. Methodology: Our study used a questionnaire to examine the recreational habits of inhabitants in Romania and Hungary, in which we focused mainly on their sporting habits $(\mathrm{N}=612)$. The results obtained in the questionnaire were processed and analysed using the SPSS software. We calculated some basis statistics (mean, dispersion, median, mode). A chi2 test was used to examine the correlations. Results: The results confirm that passive recreational activities (watching TV, listening to music, reading, surfing the internet) are popular in people's lives. Hungarian respondents' activeness in sports is also confirmed as opposed to Romanian respondents. Those who do sports in their free time have noticed several positive effects on themselves. Eighty percent of respondents would be open to new methods, willing to participate in sports-related events at their workplace / school / university. The majority of respondents would do more sports if there were a person in their lives or among their acquaintances who could motivate them.
\end{abstract}

Keywords: recreational sports, prevention, motivation 


\section{Introduction}

Recreational sports have many known positive effects on a person's physical, mental, and social well-being, which has been confirmed by several Hungarian (Apor, 2011; Juhász et al., 2015; Müller and Bácsné, 2018; Simon et al., 2018) and international (Dobay et al., 2017; Bendíková et al., 2018; Baidog and Herman, 2018; Erdely et al., 2020) literature sources. Nowadays, stress and stress-related diseases prevail because people's lives are characterized by performance and work pressure (Dajnoki et al., 2018; Héder et al., 2018; Dajnoki et al., 2019), which is accompanied by high stress levels. This is why those recreational activities have become increasingly popular that are able to reduce stress levels, such as massage (Bíró et al., 2019) or certain exercise programs (Csörgő et al., 2013; Bodolai et al., 2016; Molnár, 2019). An increasingly greater part of society is affected by various lifestyle-related diseases like stress, anxiety, obesity, stroke, hypertension, cardiac diseases, various bad postures and deformities, which could be reduced by increased recreational sports and physical activity (Ding et al., 2017; Iski and Rurik, 2014). Sport as a "medicine of exercise" teaches a lot of things and helps to develop many positive personality traits such as perseverance, selflessness, the ability to come to terms with successes and failures, fatigue tolerance, a realistic self-esteem, tolerance, while at the same time it improves will power, socialization, the development of social relations and courage. In many people's lives, sport provides the motivation to perform other tasks, as well. Active exercise could reduce the risk of the subsequent development of several diseases (Bíró, 2018). Many people die both in Hungary and Europe from cardiovascular diseases, tumorous diseases, early coronary artery diseases or suicide, which could be prevented by sport.

Many people are aware of the positive effects of sport, but they still prefer to spend their free time on passive recreational activities (Czabai et al., 2007; Kovács, 2011; Horkay et al., 2018a). Because we are overloaded, we usually do not have the mood or motivation to do sports after a long and hard day. Several studies have examined sporting habits among university students (Murányi, 2010; Kovács, 2016; Fenyves et al., 2019). Children are so engaged by the world or smartphones and the internet that they spend less and less time outdoors, do less exercise, while their personality also changes in a negative direction. Research on recreational habits draws attention to the trends affecting leisure consumption (Gődény et al., 2018; Horkay et al., 2018b; Fenyves et al., 2018; Gősi et al., 2019; Bácsné Bába et al., 2018a, b, c). Recreation is still strongly dominated by passive leisure activities (watching TV, reading, surfing the internet, listening to music), which is also confirmed by our research.

If we are able to increase people's active physical exercise and provide sufficient motivation for them, several diseases could be prevented. It is a huge problem in 
health education that people are unable to imagine the experience of a disease or the risk of even a serious damage to health (Dajnoki, 2011, 2014, 2015) during the period when they could still do the most about it, when it is not too late to change their lifestyle (Buda, 1994). We need to build a society that consciously plays sports and pays attention to its health.

\section{Methodology}

To examine the spending of free time and the presence of motivation, we designed a questionnaire-based research, in which we included questions regarding the system of recreational preference and motivational tools of the persons involved in the study. Regarding recreational habits, we also examined the frequency of the active and passive forms of activity, as well as the positive changes participants felt after doing sports. We also asked how they would act or feel if there were more sports opportunities at the workplace / school / university, what kind of lectures they would like to attend, and who motivating factors are for them.

$65 \%$ of respondents were female and $35 \%$ were male. $64.4 \%$ live in Hungary, while $35.6 \%$ in Romania. Table 1 show that there were more male respondents in Romania than in Hungary.

$68.1 \%$ of respondents were aged $19-25,13.1 \%$ were under 18 , and the rest (18.8\%) were above 26 years of age (table 2 ).

Table 1. Proportion of men and women according to country

\begin{tabular}{|c|c|c|c|c|c|}
\hline & & & In which co & o you live? & Total \\
\hline & & & Hungary & Romania & rotal \\
\hline \multirow{4}{*}{ Your gender: } & \multirow{2}{*}{ Male } & No. & 119 & 95 & 214 \\
\hline & & $\%$ & $30.2 \%$ & $43.6 \%$ & $35.0 \%$ \\
\hline & \multirow{2}{*}{ Female } & No. & 275 & 123 & 398 \\
\hline & & $\%$ & $69.8 \%$ & $56.4 \%$ & $65.0 \%$ \\
\hline \multirow{2}{*}{\multicolumn{2}{|c|}{ Total }} & No. & 394 & 218 & 612 \\
\hline & & $\%$ & $100.0 \%$ & $100.0 \%$ & $100.0 \%$ \\
\hline
\end{tabular}

Table 2. Breakdown by age

\begin{tabular}{|c|c|c|c|c|c|}
\hline \multicolumn{2}{|c|}{} & Frequency & Percent & Valid Percent & Cumulative Percent \\
\hline \multirow{5}{*}{} & $<18$ & 80 & 13.1 & 13.1 & 13.1 \\
\cline { 2 - 6 } & $19-25$ & 417 & 68.1 & 68.1 & 81.2 \\
\cline { 2 - 6 } & $26-30$ & 27 & 4.4 & 4.4 & 85.6 \\
\cline { 2 - 6 } & $31-35$ & 20 & 3.3 & 3.3 & 88.9 \\
\cline { 2 - 6 } & $36-40$ & 15 & 2.5 & 2.5 & 91.3 \\
\cline { 2 - 6 } & $41-45$ & 14 & 2.3 & 2.3 & 93.6 \\
\cline { 2 - 6 } & $46-50$ & 12 & 2.0 & 2.0 & 98.2 \\
\cline { 2 - 6 } & $51-55$ & 16 & 2.6 & 2.6 & 100.0 \\
\cline { 2 - 6 } & $56<$ & 11 & 1.8 & 1.8 & \\
\cline { 2 - 6 } & Total & 612 & 100.0 & 100.0 & \\
\hline
\end{tabular}


In order to be able to find a correlation between spending their free time and their work, first we asked respondents what kind of work they do. $70.9 \%$ are students, i.e. do sedentary work, $10.6 \%$ are not students but do sedentary work, $5.6 \%$ do physical work, while $12.9 \%$ do mixed (physical and sedentary) work. We might think that since many people lead a sedentary lifestyle, they do a lot of sports in their free time to be able to balance their lifestyle. Unfortunately, we are wrong. Most people still spend their free time with passive recreational activities. The world of media is immensely popular, also confirmed by our research, as $67.5 \%$ of respondents spend their free time with surfing the internet (on a computer, smartphone or tablet). The second most popular spare-time activity also belongs to passive recreation, as $62.7 \%$ of respondents watch TV or listens to music to relax from fatigue and try to recharge. This is followed by active recreational activity; $49.5 \%$ of respondents do sports in their free time. $46.9 \%$ like to spend their spare time in bed with passive rest and lazing around. Our research is in line with other Hungarian research findings where samples of young adults are also dominated by passive recreational activities (Müller et al., 2011; Mosonyi et al., 2013; Boda et al., 2015; Boda et al., 2019; Laoues et al., 2019). Other popular free-time activities include reading or meditation (40.7\%), housework (cleaning, cooking, doing the laundry, emptying the bins, gardening, etc.) (38.2\%), walking and playing with a pet (32.2\%), studying (25.5\%) and shopping $(22.9 \%)$, while less popular activities include attending sports events as a spectator (20.9\%), religious activities, going to church, attending diocesan programs, religious education, etc. (16.8\%), health preservation (sauna, spa) (13.2\%), playing music (8.8\%), fishing (5.7\%) and hunting (1.3\%). Several studies confirm the increased appreciation of and demand for meditation and spirituality (Lengyel, 2016, 2019). Respondents do not always do the same free-time activities, they could choose more than one answer, which is the reason of the above percentages. These figures show that although $81.5 \%$ of the people do sedentary work or both sedentary and physical work, they still spend little time with more active recreational activities. It is understandable that those who do physical work prefer to read, relax, or listen to music in their free time.

\section{Sports}

$68.3 \%$ of respondents do some exercise outside of their physical education class of duration of at least thirty minutes. This value is better than what was published earlier in a 2018 Eurobarometer study on Hungarian data, which found that in the EU, only $7 \%$ of the population do sports five or more times a week, $33 \%$ one to four times 
a week, while $14 \%$ even more rarely. In the study, $46 \%$ was the proportion of adults who never engage in regular sporting activities (Eurobarometer, 2018).

$91.3 \%$ of respondents are aware of the sporting opportunities in their environment (clubs, outdoor and indoor gyms, etc.), but still few of them go to these places.

Table 3. Are they aware of sporting opportunities?

\begin{tabular}{|c|c|c|c|c|}
\hline & \multicolumn{2}{|c|}{ In which country do you live? } \\
\hline & & & Hungary & Romania \\
\hline \multirow{4}{*}{$\begin{array}{l}\text { Are you aware of the sporting } \\
\text { opportunities in your } \\
\text { environment (clubs, outdoor } \\
\text { and indoor gyms, etc.)? }\end{array}$} & \multirow[b]{2}{*}{ Yes } & Count & 360 & 199 \\
\hline & & $\begin{array}{l}\% \text { within In which country do } \\
\text { you live? }\end{array}$ & $91.4 \%$ & $91.3 \%$ \\
\hline & \multirow[b]{2}{*}{ No } & Count & 34 & 19 \\
\hline & & $\begin{array}{l}\% \text { within In which country do } \\
\text { you live? }\end{array}$ & $8.6 \%$ & $8.7 \%$ \\
\hline \multirow{2}{*}{\multicolumn{2}{|c|}{ Total }} & Count & 394 & 218 \\
\hline & & $\begin{array}{l}\% \text { within In which country do } \\
\text { you live? }\end{array}$ & $100.0 \%$ & $100.0 \%$ \\
\hline
\end{tabular}

The most popular sports that people nowadays like to do include fitness (Gődény et al., 2018; Müller et al., 2019), running, swimming, Zumba, aerobics, football (Bácsné Bába et al., 2018b; Balogh et al., 2019), while less popular sports include basketball, tennis, and handball. These statements are also supported by our research. Most people prefer walking, hiking, Nordic walking, running, cycling, or going to fitness workouts. The least popular sports among respondents are ice hockey, golf, chess, archery, tennis, and fencing.

Note that those sports are more popular that can be done outdoors, in the nature, or even while going to school / university / work. Natural sports also play an important role in skill development and stress relief (Borbély-Müller, 2015). $21.7 \%$ of respondents like to do their exercise outdoors, in parks. They can thus devote themselves to nature and better wind down. $20 \%$ do sports at home, possibly because they do not like to go out, and this is a cost-efficient method. Since fitness is one of the popular sports, it is obvious that many people go to fitness and wellness centres to do sports. Several people do not do sports because they do not have enough spare time, so many of them do sports on their way to school / work / university. $15.7 \%$ do sports in an association or club.

Respondents mainly do sports to preserve their health and general well-being (292), but at the same time, sports make them happy (245), and furthermore, to lose weight or improve their appearance (218), but many respondents selected the "exciting and entertaining activity" option (180) as well. Very few of them do sports because others expect them to do so (18). 
Table 4. Why do you do sports? (scale 1-7)

\begin{tabular}{|l|c|c|c|c|c|}
\hline & $\mathrm{N}$ & Minimum & Maximum & Mean & Std. Deviation \\
\hline $\begin{array}{l}\text { To preserve my health and } \\
\text { general well-being. }\end{array}$ & 612 & 1.0 & 7.0 & 5.632 & 1.7079 \\
\hline To spend time with others & 612 & 1.0 & 7.0 & 3.755 & 2.1534 \\
\hline $\begin{array}{l}\text { To improve my appearance, to } \\
\text { lose weight. }\end{array}$ & 612 & 1.0 & 7.0 & 5.118 & 1.9685 \\
\hline $\begin{array}{l}\text { It makes me happy. } \\
\begin{array}{l}\text { I can get to know myself and } \\
\text { my boundaries. }\end{array}\end{array}$ & 612 & 1.0 & 7.0 & 5.312 & 1.8973 \\
\hline $\begin{array}{l}\text { It is an exciting, entertaining } \\
\text { activity. }\end{array}$ & 612 & 1.0 & 7.0 & 4.722 & 1.9929 \\
\hline $\begin{array}{l}\text { Because of others; it is } \\
\text { expected from me. }\end{array}$ & 612 & 1.0 & 7.0 & 1.742 & 1.922 \\
\hline
\end{tabular}

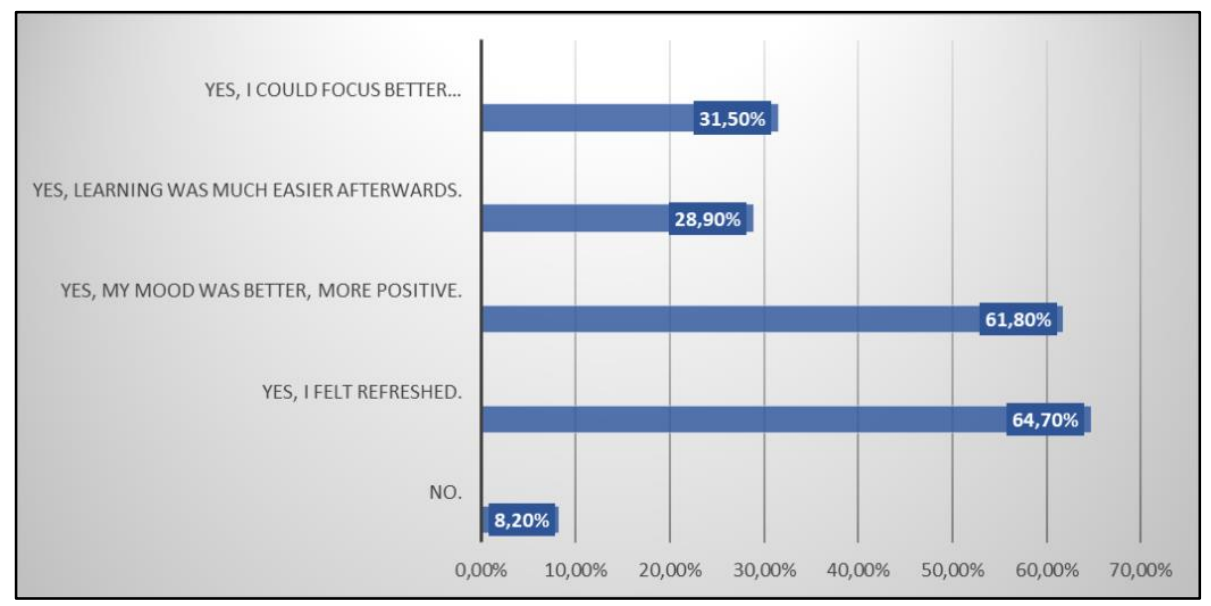

Figure 1. Positive changes after doing sports

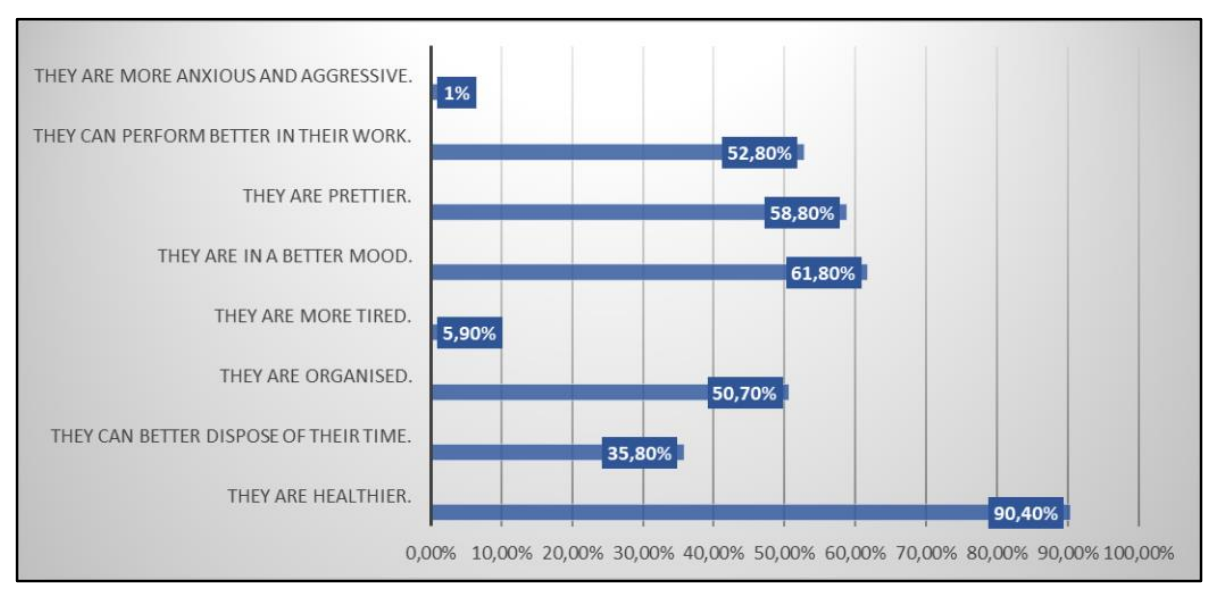

Figure 2. What are people doing sports like? 
458 people claimed that they had opportunities to do the sport they like. 115 people claimed that they would have the opportunity, but they did not have enough free time to do the active exercise. In addition, 56 people cannot afford to do sports they like.

The majority of respondents like to do sports alone (386), while 287 of them prefer to do active exercise with their friends, and 262 in a team. 87 respondents do sports within a club, 37 with a trainer. This may be due to the fact that several trainers have not yet been able to establish a close relationship with their competitors.

If the university / school / workplace organized various sports days, $80.6 \%$ of respondents would attend them. They think such events would be good entertainment opportunities, they would strengthen relationships, help them relax, improve the community, and people would be healthier and could recharge. It would be an effective method if the various companies held as many sports days as possible to get workers to do some exercise, which would result in a positive effect, as people would perform their work much more actively in the same amount of time (Hidvégi et al., 2017).

People who have already done sports felt refreshed afterwards, their mood was better, they had more positive thoughts, learning was much more efficient after sports, and they could focus better on the tasks ahead.

According to the respondents, people who do sports are healthier, their mood is better, they are prettier, more organised, they can perform better in their work, and they can better dispose of their time.

\section{Motivation}

The term 'motivation' is used to describe the psychological process underlying any behaviour (Gage and Berliner, 1991; Nagy, 2000); nevertheless, the detailed description of this process is rarely attempted, which is obviously related to the complexity of the phenomenon of motivation (Józsa, 2007).

Motivation as an umbrella term consists of various motives. It determines the degree of activity of the body, the organisation and effectiveness of behaviour, and also includes all the internal factors that encourage actions or behaviours. The internal urge that affects an individual can be of different origins. It is called a need if the sources of the stimulus are biological motives (hunger, lack of oxygen, etc.); however, if the internal urge is of a psychological origin, we speak about drive (Freud's "instinct"), which is a kind of psychological driving force to achieve an individual's set goals or an organization's internal state of equilibrium or so-called "homeostasis". There are, however, motivational "channels" that are unique to the human race. We can distinguish two types. One is "intrinsic" motivation where the stimulus for action is the inherent enjoyment in the act itself. The other group of human motivation is 
"extrinsic" or performance-driven motivation where the urge comes from the achievement of a goal (e.g. breaking out of poverty) or an external factor (Lenténé, $2014,2017)$. These can appear in various forms in the different areas of life.

The presence of adequate motivation is particularly important for sports (Fyodorov et al., 2019; Bendíková and Dobay, 2017; Kozma et. al., 2015; Tătar et. al., 2018; Buhaș-Stance, 2017). Many people do not do sports because they are not motivated. We asked respondents who had motivated them to start to do sports. 518 of them started to do sports on their own initiative. 176 people were encouraged by friends, while 148 of them by parents. Few of them were motivated by siblings, teachers, trainers, or doctors. There should be an increase in the number of parents motivating children to do sports, as several studies discuss the determining role of the family or parent (Laoues, 2019; Mező and Mező, 2017; Herpainé, 2018; Kőnig-Görögh et al., 2019). The more parents do active physical exercise, the more children would be involved in the world of sports.

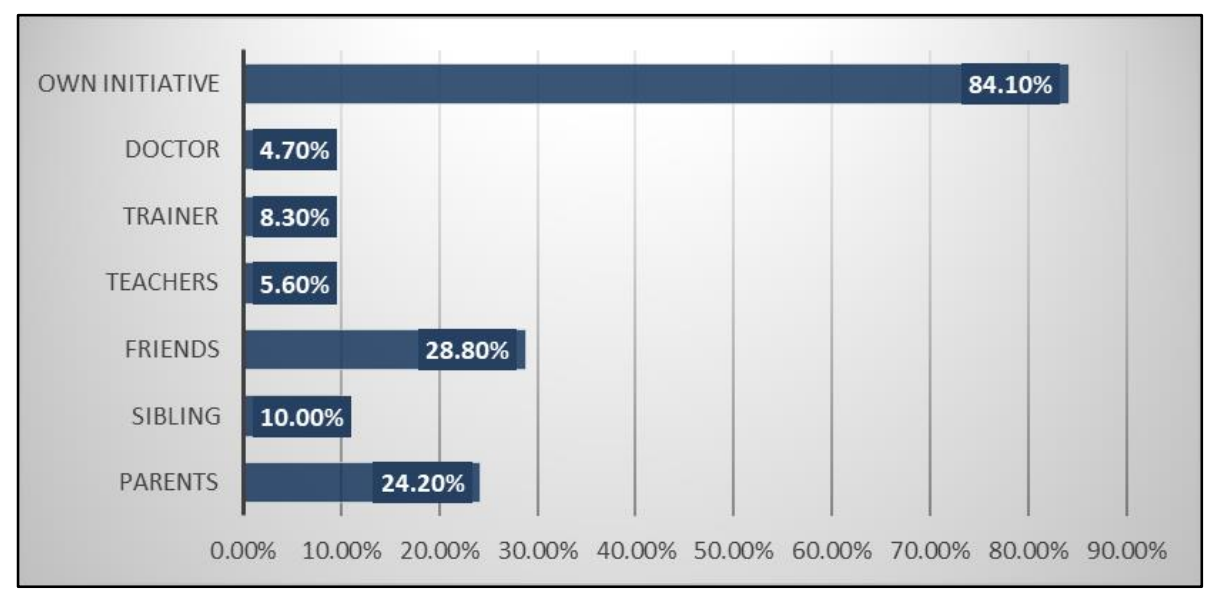

Figure 3. Who motivated them to do sports?

Motivation is essential in sports, since it affects all factors that influence performance: these include physical fitness, technical and tactical training, mental preparation, as well as everyday lifestyle. Respondents are aware of the positive effects of sport, and probably that is why they responded that if they have or will have children, they would motivate them to do sports (99.5\%).

Most people have found the person with whom they would like to train, as $78.6 \%$ of respondents replied that there is a person in their environment whom they could ask to motivate them to do sports, or if this person invited them to do sports, they would gladly join them. 
People are interested in many topics. We asked what kind of lectures they would like to attend. 292 respondents are interested in the topic of the appropriate trainings and losing weight, 287 would participate in personality development trainings, 276 in motivational lectures, and 252 people would be attracted most to lectures on healthy eating.

\section{Of the experience of correlation analysis}

Sporting activity of Hungarians was higher than that of Romanians, as $71.6 \%$ of Hungarian respondents (282 people), while $62.4 \%$ of Romanians (136 people) claimed that they do sports (defined as doing recreational sports at least once a week, at least for 30 minutes). The chi2 test also confirmed the higher sporting activity of Hungarians (chi2 $=5.473, \mathrm{df}=1, \mathrm{p}=0.013$ ).

A significant difference was found between Hungarian and Romanian respondents also regarding the frequency of doing sports (chi2 $=13.521, \mathrm{df}=5$, $\mathrm{p}=0.019$ ). There are more Hungarians who do sports as frequently as $2-3$ or 3-5 hours a week, and there are fewer people among them who do not do sports at all, compared to Romanians (table 5).

Table 5. How much sports do you do?

\begin{tabular}{|l|c|c|}
\hline & Romanian & Hungarian \\
\hline I do sports for 3-5 hours a week. No. & 33 & 84 \\
\hline I do sports for 3-5 hours a week. \% & $15.1 \%$ & $21.3 \%$ \\
\hline I do sports for 2-3 hours a week. No. & 45 & 112 \\
\hline I do sports for 2-3 hours a week \% & $20.6 \%$ & $28.4 \%$ \\
\hline I do sports for 5-8 hours a week. No. & 39 & 56 \\
\hline I do sports for 5-8 hours a week. \% & $17.9 \%$ & $14.2 \%$ \\
\hline I do sports for 8-10 hours a week. No. & 19 & 34 \\
\hline I do sports for 8-10 hours a week. \% & $8.7 \%$ & $8.6 \%$ \\
\hline $\begin{array}{l}\text { I do not do sports. I walk or cycle sometimes, not } \\
\text { more than 1 hour. No. }\end{array}$ & 68 & 82 \\
\hline $\begin{array}{l}\text { I do not do sports. I walk or cycle sometimes, not } \\
\text { more than 1 hour \% }\end{array}$ & $31.2 \%$ & $20.8 \%$ \\
\hline I do sports for more than 10 hours a week. No. & 14 & 26 \\
\hline I do sports for more than 10 hours a week. \% & $6.4 \%$ & $6.6 \%$ \\
\hline
\end{tabular}

Health as a motivation for sports is a stronger motivation among Hungarians than the Romanian respondents, as $52.3 \%$ of Hungarians rated it ' 7 ', i.e. being fully characteristic of them, while only $39.4 \%$ of Romanians rated it ' 7 ' on the Likert scale (chi2=22.03, $d f=6, p=0.001$ ). The results show a strongly significant difference between the nationalities.

"Spending time with others", i.e. community as a motivation for sports showed no significant difference. 
The motivation of appearance and losing weight in recreational sports is also more characteristics of Hungarians, as $21.3 \%$ of them (84 people) rated it ' 6 ' and $38.6 \%$ of them (152 people) rated it ' 7 ', while only $12.8 \%$ of Romanian respondents rated it ' 6 ' and $30.3 \%$ of them ( 66 people) rated it '7' (chi2 $=33.82$, $\mathrm{df}=6, \mathrm{p}=0.000$ ).

Sport as a happiness factor also appears more dominant in Hungarian respondents' system of values, as $20.1 \%$ of Hungarians rated it ' 6 ' and $42.9 \%$ (169 people) rated it ' 7 ', while only $12.8 \%$ of Romanians (28 people) rated this motivational factor ' 6 ' and 34.9\% (76 people) rated it ' 7 '. (chi2=37.548, df=6, $\mathrm{p}=0.000$ ).

The motivation that "I can get to know myself and my boundaries" also appears more strongly in Hungarians' motivation for sports, as there were more respondents among Hungarians who rated this motivation ' 5 ', ' 6 ' or '7' (chi2=25.567, df=6, p=0.000).

Being an exciting and entertaining activity as a motivation for recreational sports is also much stronger among Hungarian respondents than among Romanians, as $20.8 \%$ of Hungarians (82 people) rated it ' 6 ' and $32 \%$ (126 people) rated it '7', while $15.1 \%$ of Romanian respondents (833 people) rated this motivation ' 6 ' and $24.8 \%$ (54 people) rated it ' 7 '. (chi2=19.136, $\mathrm{df}=6, \mathrm{p}=0.004$ ).

"It is expected from me" as a motivation had a low average among both nationalities, i.e. it is a less important aspect in doing sports. Respondents were consistent in this response, as we could show no significant difference.

\section{Conclusions}

It is important to increase participation in regular recreational sports in Hungary because we perform below the EU average for all age categories.

Our research proves that although recreational sports do appear among people's recreational activities, passive free-time activities are still more common. It would be desirable to train experts who could provide sufficient motivation for people, because if we increased motivation for and interest in sports in people's lives, we would reduce the risk of certain diseases, and we could improve people's physical, mental and social well-being. As doing sports is a personality development activity that psychologically connects people, enhances physical fitness, has antidepressant and energizing effects, active exercise can affect our mood and relationships.

\section{Acknowledgements}

This publication was supported through project no. EFOP-3.6.2-16-2017-00003. The project was supported by the European Union and co-financed by the European Social Fund. 


\section{References}

Apor, P. (2011). Measure of fitness and physical activity related to cardiovascular diseases and death. Orvosi hetilap, 152(3), 107-113.

Bácsné Bába, É., Fenyves, V., Szabados, G., Pető, K., Bács, Z., \& Dajnoki, K. (2018a). Sport Involvement Analysis in Hungary, in the North Great Plain Region. Sustainability, 10(5), 1629. doi: $10.3390 /$ su10051629.

Bácsné Bába, É., Fenyves, V., Dajnoki, K., \& Szabados, G. N. (2018b). Analysis of the supply of sports services based on organizational aspects. International Journal of Engineering and Management Sciences, 3(4), 465-474.

Bácsné Bába, É., Pfau, C., Dajnoki, K., \& Müller, A. (2018c). Examining the quality parameters of sports services. In: Šimonek, J., Dobay, B. (eds.) Sport science in motion: proceedings from the scientific conference. Športová veda $\mathrm{v}$ pohybe: recenzovaný zborník vedeckých a odborných prác z konferencie. 324 p. Komárno: Univerzita J. Selyeho, pp. 236-243. ISBN: 978-80-8122-245-0

Baidog, A., \& Herman, G.V. (2018). The Influence of Sports and Physical Activity on the Metabolic Syndrome: A Systematic Review. Analele Universităţii din Oradea. Fascicula Educaţie Fizică şi Sport, 28(1), 39-45.

Balogh, R., Dajnoki, K., \& Bácsné Bába, É. (2019). Why is Hungarian football still sick? - Description of the player market of Hungarian soccer. Jelenkori Társadalmi és Gazdasági Folyamatok, 13(3-4), 105-117.

Bendíková, E., \& Dobay, B. (2017). Physical and Sport Education as a Tool for Development of a Positive Attitude toward Health and Physical Activity in Adulthood. European journal of contemporary education, 6(1), 14-21.

Bendíková, E., Marko, M., Müller, A., \& Bába, É. B. (2018). Effect of applied health-oriented exercises in physical and sport education on musculoskeletal system of female students. Acta Facultatis Educationis Physicae Universitatis Comenianae, 58(2), 84-96.

Bíró, M. (2018). Introduction to sports pedagogy. In: Münnich, Á. (ed.) Chapters on sports psychodiagnostics and counselling. Debrecen, Hungary: University of Debrecen, Faculty of Humanities, Institute of Psychology, (2018) Paper: http://psycho.unideb.hu/sport/fejezetek/bm_sportpedagogia/_book/index.html

Bíró, M., Molnár, A., Hídvégi, P., Mikhárdi, S., Pucsok, J. M., \& Lenténé, P. A. (2019). The role of massage in tourism, and the hotels offerings in Hungary. In: Sport science in motion: Proceedings from the scientific conference Zborník vedeckých a odborných prác z vedeckej konferencie. UNIVERZITA J. SELYEHO V KOMÁRNE, pp. 27-36.

Boda, E. J., Bácsné Bába. É., Laoues-Czimbalmos, N., \& Müller, A. (2019). An analysis of recreational consumer habits among Hungarian young adults. Különleges Bánásmód, 5(4), 33-44.

Boda, E., Honfi, L., Bíró, M., Révész, L., \& Müller, A. (2015). The analysis of spending leisure time and recreational activities among inhabitants of Eger. Acta Academiae Paedagogicae Agriensis Nova Series: Sectio Sport, 42, 49-62.

Bodolai, M., Lívják, E., Boda, E., \& Bíró, M. (2016). The effect of yoga on the body and its role in stress management. Acta Academiae Agriensis. Sectio Sport, 51-67.

Borbély, A., \& Müller, A. (2015). Sports and tourism, Debrecen, Magyarország: Campus Kiadó (2015), 110 p. ISBN: 9789639822368

Buda, B. (1994). The concept of sports mental health. In: Mentálhigiéné. Tanulmánygyűjtemény. Animula, Budapest, 257-284, 1994.

Buhaș, S., \& Stance, L. (2017). The Relationship between Personality and Physical Activity. GeoSport for Society, (7), 2, 72-77.

Csörgő, T., Bíró, M., Kopkáné Plachy, J., \& Müller, A. (2013). Effects of massage therapy on women over sixty years. Acta Academiae Agriensis. Sectio Sport, 5-16.

Czabai, V., Bíró, M., \& Hajdu, P. (2007). The lifestyle and sporting habits of the students of Eszterházy Károly College. Acta Academiae Paedagogicae Agriensis. Sectio Sport, 29-38.

Dajnoki, K. (2011). Conflict treatment in the equal employment opportunity human resource management. Acta Scientiarum Socialium, 33, 77-85. 
Dajnoki, K. (2014). The exploration of HR characteristics on the basis of in-depth interviews conducted with leaders of organisations employing people with disabilities. Közép-Európai Közlemények. VII (26-27), 185-195.

Dajnoki, K. (2015). Judgement Of The Factors Influencing The Integration Of The Employees With Disabilities Or Reduced Work Capacitiy Into Workplaces In The Northern Great Plain Region. The Annals of the University of Oradea, 506-514.

Dajnoki, K., Halász, P., Kőmíves, P.M., Szabados, Gy., \& Bácsné Bába, É. (2019). Airsoft prospects: sports and the organizational side. Hadtudomány 29: E-szám pp. 105-115. 10.17047/HADTUD.2019.29.E.105

Dajnoki, K., Szabados, G. N., \& Bába, É. B. (2018). A Case Study on Human Resource Management Practice of a Sport Organization. International Journal of Engineering and Management Sciences, $3(4), 410-425$.

Ding, D., Kolbe-Alexander, T., Nguyen, B., Katzmarzyk, P. T., Pratt, M., \& Lawson, K. D. (2017). The economic burden of physical inactivity: a systematic review and critical appraisal. Br J Sports Med, 51(19), 1392-1409.

Dobay, B., Müller, A., \& Bendíková, E. (2017). Adult Health in Terms of Selected Lifestyle Factor. Disputationes Scientificae Universitatis Chatholicae. In Ruzomberok, 17(4), 32-39.

Erdely, Ș., Caciora, T., Șerbescu, C., Papp, B. M., Tamas, F. A., Bujorean, E., ... \& Herman, G. V. (2020). Trends in the lifestyle of students. Case study of a high school in Oradea, Romania. Geosport for Society, 12(1), 1-12.

Eurobarometer, 2018 Special Eurobarometer 472, Sport and physical activity, https://www.loketgezondleven.nl/sites/default/files/2018 12/Eurobarometer_472_PhysActivSports2018.pdf

Fenyves, V., Dajnoki, K., \& Bácsné Bába, É. (2018). Assessment of sport activities among higher education students in Eastern Europe. SEA - Practical Application of Science, VI: 3, 347-353.

Fenyves, V., Dajnoki, K., Kerezsi, D., \& Bába, É. B. (2019). Analysis of Sport Motivation Factors amongst Eastern European Higher Education Students. European Journal of Contemporary Education, 8(4), 761-778.

Fyodorov, A. I., Erlikh, V. V., Khafizova, A., \& Bendikova, E. (2019). Young students' health attitudes. Journal of Physical Education and Sport, 19(4), 2512-2517.

Gage, N. L., \& Berliner, D. C. (1991). Educational Psychology. Houghton Mifflin Company, Boston.

Gődény, N., Bíró, M., Lenténé Puskás, A., Lente, L. \& Müller, A. (2018). An analysis of changing consumer habits and trends in the field of fitness. In: Balogh, László (ed.) Fókuszban az egészség. University of Debrecen, Sports Science Coordination Institute, Debrecen. 9-18.

Gősi, Zs., Boros, Sz., \& Patakiné Bősze, J. (2019). Diverse Recreation: Studies on recreation. Budapest, Hungary: Eötvös Loránd University, Faculty of Pedagogy and Psychology, 140 p. ISBN: 9789634891116

Héder, M., Szabó, Sz., \& Dajnoki, K. (2018). Effect of Labour Market Changes on HR Functions. Anali Ekonomski Fakulteta U Subotici / The Annals of the Faculty of Economics Subotica, 54, 123-138.

Herpainé Lakó, J. (2018). Three-generation research concerning sport and value. In: Šimonek, J.; Dobay, B. (eds.). Sport science in motion: proceedings from the scientific conference. Športová veda v pohybe: recenzovaný zborník vedeckých a odborných prác z konferencie. Mozgásban a sporttudomány: válogatott tanulmányok a konferenciáról. Komárno, Slovakia: Univerzita J. Selyeho, (2018) pp. 274-280., 7 p.

Hidvégi, P., Bíró, M., Müller, A., \& Váczi, P. (2017). Psychical education program in health promotion. Acta Academiae Paedagogicae Agriensis Nova Series: Sectio Sport, 44, 115-138.

Horkay, B., Lenténé Puskás, A., \& Bíró, M. (2018a). The supply elements and the recreational possibilities in the city and in the countryside. In: Šimonek, J.; Dobay, B. (eds.). Sport science in motion: proceedings from the scientific conference. Športová veda v pohybe: recenzovaný zborník vedeckých a odborných prác z konferencie. Mozgásban a sporttudomány: válogatott tanulmányok a konferenciáról. Komárno, Slovakia: Univerzita J. Selyeho, (2018) pp. 330-339., 10 p.

Horkay, B., Lenténé Puskás, A., \& Bíró, M. (2018b). The comparison of the supply elements and recreational possibilities of the city and the countryside in light of a research. In: Balogh, L. (ed.) 
Fókuszban az egészség. Debrecen, Hungary: University of Debrecen, Sports Science Coordination Institute, (2018) pp. 94-105., 12 p.

Iski, G., \& Rurik, I. (2014). The estimated economic burden of overweight and obesity in Hungary. Orvosi Hetilap, 155 (35), 1406-1412.

Józsa, K. (2007). Mastery Motivation. Műszaki Kiadó, Budapest.

Juhász, I., Kopkáné Plachy, J., Kiszela, K., Bíró, M., Müller, A., \& Révész, L. (2015). The impact of recreational physical activity on the cardiorespiratory system in the elderly. Magyar Sporttudományi Szemle, 16(63), 4-8.

Kőnig-Görögh, D., Szerdahelyi, Z., Czimbalmos-Laoues, N., \& Olvasztóné Balogh, Zs. (2019). A comparative analysis of the physical development and motor level in Hungarian kindergarten pupils aged 4-6. In: Pálfi, S. (ed.) Early childhood education, families and communities: EECERA 2018 Conference Organized by the Faculty of Child Education and Special Education of the University of Debrecen. Debrecen, Hungary: Didakt Kft., pp. 95-107.

Kovács, K. (2011). Leisure time and sports at the University of Debrecen. Iskolakultúra, 21(10-11), 147-162.

Kovács, K. (2016). Institutional factors in students' sports activity at the University of Debrecen in light of a qualitative research. In: Mrázik J. (ed.): New ways of learning. Budapest, HERA könyvek, 665-675.

Kozma, G., Bacs, Z., \& Zilinyi, Z. (2015). The possibilities and results for the scientific research into the relationship between settlements and sport. Geosport for Society, 3(2), 41-52.

Laoues-Czimbalmos, N., Dobay, B., \& Müller, A. (2019). Examination of the Leisure Time-Related Consumption Habits of Young People with Disabilities with Special Emphasis on Sports. Selye EStudies, 10(2) 34-45.

Lengyel, A. (2016). Tourism, meditation, sustainability. Apstract - Applied Studies in Agribusiness and Commerce, 10(1), 81-92.

Lengyel, A. (2019). An increased interest in mindfulness and liminality: Spiritual retreat centres as destinations of a sustainable future? Turizmus Bulletin, 19(1),14-24.

Lenténé Puskás, A. (2014). Opportunities of a dual career for top athlete university students. Taylor: Gazdálkodás- és Szervezéstudományi Folyóirat: A virtuális Intézet Közép-Európa Kutatására Közleményei, 1-2,403-412.

Lenténé Puskás, A. (2017). Opportunities and challenges of coordinating a sports career and one's studies at the University of Debrecen. Doctoral Dissertation.

Mező, F., \& Mező, K. (2017). Parents' educational style and its effect on the children's behaviour. The pedagogical reasons of escaping from the family. In: Vargáné Nagy, A. (ed.) Családi nevelés 2. Debrecen, Hungary: Didakt Kft., 50-66.

Molnár, A. (2019). Fitness trends in the service of health. In: Bácsné Bába, É., Müller, A. (eds.). "Movement for health". The importance of physical activity in health protection of future workers: International Conference and Workshop: Proceedings from the International Conference and Workshop. Debrecen, Hungary: University of Debrecen, (2019) pp. 113-120.

Mosonyi, A., Könyves, E., Fodor, I., \& Müller, A. (2013). Leisure activities and travel habits of College students in the light of a survey, Apstract - Applied Studies in Agribusiness and Commerce, 7(1), 57-61.

Müller A., \& Bácsné Bába, É. (2018). Connection between a healthy lifestyle and sports. Létavértes, Hungary: Létavértes SC '97 Egyesület (2018), 96 p. ISBN: 9786150031897.

Müller A., Lengyel A., Koroknay, Zs., \& Molnár, A. (2019). Popular fitness movements. In: Bácsné Bába, É., \& Müller, A. (eds.) "Movement for health" The importance of physical activity in health protection of future workers: International Conference and Workshop: Proceedings from the International Conference and Workshop. Debrecen, Hungary: University of Debrecen, (2019) pp. 106-112 , 7 p.

Müller, A., Kerényi, E., \& Könyves, E. (2011). Effect of climate therapy and rehabilitation in Mátra Medical Institute. Apstract - Applied Studies In Agribusiness and Commerce, 5(3-4), 39-42.

Murányi, I. (2010). Leisure activities and the mental state of university students. Educatio, 203-213.

Nagy, J. (2000). The 21st century and education. Osiris Kiadó, Budapest.

Simon, I. Á., Kajtár, G., Herpainé Lakó, J., \& Müller, A. (2018). The significance of physical activity and mental health in the life of people over 60. Képzés És Gyakorlat: Training And Practice, 16(1), 25-36.

Tătar, C. F., Herman, G. V., \& Pețan, P. (2018). Sport and physical activity engagement in Romania. Geosport for Society, 8(1), 40-50. 